\title{
Aspectos visuais e sonoros de Um lance de dados
}

\author{
Visual and audible aspects of $A$ throw of dice \\ Larissa Drigo AGOSTINHO* \\ Universidade de Paris IV-Sorbonne
}

\begin{abstract}
RESUMO: Procuramos neste texto apresentar os procedimentos formais mais inovadores de $\mathrm{Um}$ Lance de dados, como a dupla página, a utilização de diferentes caracteres tipográficos e o caráter sonoro do poema mostrando a importância destes elementos na constituição da poética mallarmeana, na construção de uma noção de forma capaz de fazer do acaso o seu princípio constitutivo.
\end{abstract}

PALAVRAS-CHAVE: Acaso. Escrita. Som. Ideia. Tempo.

RÉSUMÉ: Dans ce texte nous présenterons les procédures formels et techniques innovatrices du poème Un coup de dés, comme la double page, l'utilisation de différents caractères typographiques et le caractère sonore du poème, en montrant l'importance de chaque élément dans la constitution de la poétique mallarméenne, dans la construction d'une notion de forme que fait du hasard son principe constitutif.

MOTS-CLES: Hasard. Écriture. Son. Idée. Temps.

\section{Introdução}

A poesia, ou as Letras, se constituem, grosso modo, segundo Mallarmé, a partir da união entre as letras e a música, entre os caracteres escritos na página e a sonoridade das palavras. E é justamente realizando a união desses elementos concretos que o poeta constrói sua poesia, a partir de uma leitura literal, portanto, do que seriam as Letras e a Música. Mas é importante ressaltar que tanto a Música como as Letras podem também, ser entendidas como formas mais amplas, ideias gerais da forma poética ou ideais artísticos.

Em "Notas sobre a linguagem" encontramos o seguinte trecho:

Daí as duas manifestações da Linguagem, a Fala e a Escrita, destinadas (se nos atermos aos dados de Linguagem) a se reunirem ambas na ideia do Verbo: a Fala (criando analogias de coisas pelas analogias de sons) $\left[f^{\circ} I\right.$ ) a Escrita marcando os gestos da Ideia se manifestando na fala, e oferecendo sua reflexão, de maneira a perfazer, no presente (pela leitura), e a conservá-las para o futuro como anais do esforço sucessivo da fala e de sua filiação: e a dar o parentesco.

De maneira que um dia, suas analogias contrastadas, o Verbo apareça por trás de seu meio de linguagem, entregue a física e a fisiologia, como um princípio, desprendido, adequado ao Tempo e à Ideia. (MALLARMÉ, 1998, p. 506) ${ }^{1}$

\footnotetext{
* Bacharel em letras pela Universidade de São Paulo, mestre em filosofia pela Universidade de Paris I e mestre e doutoranda em literatura francesa pela Universidade de Paris IV-Sorbonne, França. Email: larissa_drigo@yahoo.com.br

${ }^{1}$ As traduções do francês são todas da autora.

(C) Revista Moara ISSN 0104-0944 (Impresso), n.37, jan.-jun., Estudos Literários, 2012.

Programa de Pós-Graduação em Letras / Universidade Federal do Pará. Todos os direitos reservados.
} 
A linguagem possui dois modos de manifestação concretos, duas formas de ser, a escrita e a fala. Esses dois elementos compõem a "Ideia do Verbo", ou a poesia. A fala cria analogias entre coisas ao estabelecer analogias entre sons. Ela coloca em relação às coisas através de uma espécie de rima que aproxima universos distintos, criando novos sentidos, novas relações, novos significados. A fala também possui um caráter gestual, ao criar analogias entre as coisas e os sons ela inscreve o sentido enquanto som, pois o gesto "sonoro", enquanto forma abstrata, sem determinação concreta, enquanto forma que se dissolve no espaço e no tempo, é também uma forma de presentificação da ideia.

Já a escrita evoca a objetividade da linguagem, seu caráter concreto, visual. Através da escrita, a linguagem é compreendida como um modo de ação. Ela é assim a marca dos gestos da ideia que se manifesta pela fala. A escrita é gestual, ela encarna a objetividade do teatro, mas sua existência é fulgurante, seus gestos são o da ideia, que se manifesta na fala, pura dissolução de si mesma. Assim a escrita reflete a ideia que se manifesta na música, ela escreve a ideia mesma do som. Com a escrita, a sonoridade se transforma num traço, concreto, numa marca. A escrita fixa o que a música dissolve.

Este modo de ser da linguagem, visual e sonoro, é a própria exposição do modo de ser da linguagem segundo Mallarmé, que deve ser adequado ao Tempo e à Ideia. O que interessa é o sentido, o significado deste movimento, pois não se trata de fazer um elogio do inefável, mas sim de unir os elementos opostos da linguagem, a fala e a escrita "de maneira a perfazer no presente (pela leitura) e a conservá-las para o futuro". De maneira que esses opostos não se anulem, mas sejam capazes de instaurar um presente, de indicar um futuro. Desta maneira, através da fala e da escrita, o tempo não é somente dissolução, mas inscrição. Há algo neste ato momentâneo da ideia, na música do poema, que se conserva, que se mantém irredutível sob a página: as próprias Letras.

Trata-se aqui, portanto, de uma discussão sobre a relação entre a poesia e a música, na qual a primeira se define a partir da segunda, de uma reflexão sobre a natureza da linguagem que desvelar o processo de constituição de todo significado, como modo de ser contraditório, entre a ausência e a presença. Ausência do objeto que é marca da presença da palavra. Assim, o que está em questão é a exposição do mecanismo representativo que busca reconfigurar o presente, reconfigurar nossa ideia de presente, nossa ideia de poesia, reconfigurar a poesia do presente. Há algo que se diz no movimento de desvanescimento da linguagem, na exposição e desvelamento da representação, e é este dito que permanece sob a folha de papel, porque só seria poesia capaz de fixá-lo.

\section{Um lance de dados: a revolução poética}

Segundo Julia Kristeva (1974), a França, no fim do século dezenove, foi palco de uma verdadeira revolução literária, uma revolução que ocorreu através da transformação da linguagem poética. Seus principais atores seriam Lautréamont e Stéphane Mallarmé. A obra mallarmeana responsável por essa revolução seria o poema Un coup de dés.

Publicado pela primeira vez em 1897, na revista "Cosmopolis", dois anos antes da morte do autor, em seguida publicado em livro, edição póstuma, mas que segue minuciosamente as instruções e anotações do poeta, o poema é uma obra madura, coroamento de uma carreira poética que se define pela grande consciência do poeta com relação à sua arte.

Não se trata aqui de realizar uma análise minuciosa do poema, pretendemos simplesmente fornecer ao leitor algumas indicações primeiras de leitura, definindo a estrutura do poema, sobretudo no que diz respeito à relação entre a tipografia e seus aspectos "sonoros" e como estes dois momentos compõem uma ideia de linguagem, ou a 
ideia mesma da linguagem. Ou seja, pretendemos compreender de que maneira Mallarmé entende o poema como espaço de reflexão da linguagem e sobre a linguagem.

Toda a problemática do poema Un coup de dés está presente décadas antes de sua publicação, no conto Igitur. Trata-se de um conto filosófico, dirigido, segundo o poeta, à inteligência do leitor, que deve colocar as coisas em seu devido lugar. Neste conto, o poeta narra um percurso realizado pela inteligência, uma luta travada entre o sujeito e sua própria razão contra o acaso e a impotência. Igitur "desce as escadas, do espírito humano, vai ao fundo das coisas: em "absoluto" que ele é" (MALLARMÉ, 1998, p. 474). O trecho, que vem a seguir, resume a problemática do poema, o dilema da razão e da poesia diante do acaso, ele especula sobre as possibilidades de ação do pensamento diante da onipresença e onipotência do acaso:

\footnotetext{
Que uma fala lançada sobre os dados, pois não pode ser com certeza que uma fala, não se realize, como havia segundo o pensamento, II chances que ela não se realizasse contra uma, o acaso se afirma com relação à fala, se negando com relação ao pensamento - Pois o acaso foi que a fala se realizou. Todavia se ela se realiza o acaso se nega quanto à fala, se afirmando com relação ao pensamento, pois essa deve. (MALLARME, 1998, p. 476)
}

Segundo o pensamento há duas chances contra uma de que a fala não se realize, pois o acaso está do lado da fala ou do pensamento, se a fala se realiza o acaso se nega com relação a ela, mas se afirma com relação ao pensamento. A realização da fala ou do poema se deve ao ato de abolição do acaso. Em compensação, quando o acaso se nega em relação à fala e ao poema, ele se afirma em relação ao pensamento, o que significa que o poema não pode estar em harmonia com a razão na presença do acaso, pois este impede que o poema se realize, que a ideia encontre a fala e se exprima.

Mallarmé (2003) problematiza a criação poética, mostrando que nem sempre o poeta é capaz de exprimir exatamente aquilo que pensa, pois na verdade o pensamento também é marcado pela presença do acaso. Assim, escrever seria outra coisa, muito além de exprimir ideias claras numa linguagem límpida. Acaso e pensamento não são termos opostos, o acaso não é simplesmente uma força exterior que impede a expressão, que interfere no pensamento, ele deve ser compreendido como o próprio modo de funcionamento do pensamento. Por isso a poesia deve encontrar uma forma capaz de acolher o acaso, sem desfigurá-lo, sem buscar ou provocar a ilusão de poder controlá-lo, procurando na verdade potencializar o acaso, criando as condições ideais para que ele possa agir e interagir com as palavras, transformando-as, criando sentidos. Mas isso não significa uma entrega total ao acaso, como John Cage procuraria fazer com a sua música anos depois; isso não significa também a "disseminação" total do sentido como queria Derrida. O que Mallarmé procura é o equilíbrio difícil, entre o controle e o abandono, o ponto em que uma diferença mínima entre os dois aparece que não é, no entanto, suficiente para que acaso e pensamento possam se distinguir e se excluir mutuamente.

Un coup de dés formaliza, portanto a questão central de Igitur. O poema responde poeticamente a uma questão que só poderia se resolver desta maneira, formalmente, isso quer dizer que se Igitur permaneceu inacabado é porque a forma do conto não era capaz de responder à questão do acaso. É esta ideia que pretendemos demonstrar.

O poema Un lance de dados já não tem mais como personagem principal Igitur, essa conjunção, mas um outro "Le Maître", o mestre, ou o "metro", alter-ego do poeta, e nome mesmo da forma poética, do princípio através do qual a poesia é racionalizada, é ele, o mestre, o poeta, que surge aqui, para lançar os dados, não sem antes, como Hamlet, hesitar. 
Se Igitur é a conjunção que procura ligar dois termos distintos, acaso e pensamento, no poema esta função é do poeta, o mestre que deve, no verso, "remunerar o defeito das línguas". Aqui o poeta não se esconde mais atrás de seu personagem, ele resolve diretamente expor seu drama, problematizar a criação, transformando-a no tema, na forma mesma do poema.

Aqui já não estamos mais no terreno da prosa, mas sim do verso, um verso certamente muito diferente da tradição francesa e da poesia parnasiana. A questão aqui gira em torno do maître/mètre, que é mestre e metro ao mesmo tempo, poeta e prosódia, o que indica que o conflito do poema gira explicitamente em torno da sua própria execução. Un coup de dés mantém, no entanto, a "estrutura" narrativa do conto, mais aqui estamos diante da narração de uma hesitação. Os tempos verbais são o subjuntivo e o condicional, "tout se passe, par raccourci en hypothèse", como se o poeta refletisse sobre o ato poético, sobre a possibilidade de existência da poesia. A questão existencialista de Hamlet é aqui a da existência da própria poesia. O poeta exita entre ser e não-ser, entre agir ou se calar, sua questão é: lançar ou não lançar os dados? Escrever ou não escrever?

"O mestre" ("Le maître") hesita porque sabe que se os dados forem lançados, o número viria pelo acaso, ou seja, o ato de lançar os dados é sempre uma confirmação do acaso: "SI C'ÉTAIT UN NOMBRE CE SERAIT LE HASARD”. ("se houvesse um número, seria [...] o acaso) (MALLARMÉ, 2003, p. 432).

O conflito principal é, portanto, a luta contra o acaso, que não se deixa resumir pelo cálculo das probabilidades ou ao cálculo das sílabas do verso: "LE MAÎTRE" "surgi" "pour le jeter" para lançar os dados, no entanto, ele "hesite", "ancestralement à n'ouvrir pas la main", trata-se do "l'ultérieur démon immémorial" que "induit", "dans des contrés nulles", "le vieillard vers cette conjonction suprême avec la probabilité".

Este demônio, "né / d'un ébat", "la mer par l'aïeul tentant et l'aïeul contre la mer", representa o noivado, "Fiançailles", união entre o pensamento e o acaso. Mas o velho sabe que vencer o acaso é uma loucura, "folie".

As duas páginas que seguem apresentam o que seria esta loucura. Trata-se do desejo de eliminar o acaso, que transforma o mestre em "prince amer de l'écueil", seduzido pelo canto de uma sereia, este ser de ficção que provocaria a sua perdição, o naufrágio do homem "faux manoir/ évaporé en brumes". Diante da impossibilidade de eliminar o acaso, o poema afirma que não há, portanto, um ato possível, "RIEN N'AURA EU LIEU QUE LE LIEU", que nada pode acontecer.

Desta forma a hesitação do mestre é um questionamento sobre a possibilidade mesma da literatura. Diante do acaso, nenhum ato parece possível, pois se esse não pode ser abolido, o pensamento será sempre impotente. E a poesia impossível. No entanto, parece haver um momento excepcional, uma exceção que permitiria ao poema realizar-se, mas com uma condição, a de que o poema seja como uma constelação, sem as barragens do mar que impõem limites ao infinito, como o espaço onde toda realidade se dissolve, mas que serve, no entanto, como guia para os navegantes, para os homens. Na constelação, o caminho do poema parece estar escrito. Este lugar excepcional, este lugar de exceção que é o poema, o fundo do naufrágio do homem, talvez possa funcionar como o espaço de onde emergiria uma nova gramática, uma nova sintaxe de nossos desejos, gestos e ações.

No prefácio do poema, na edição da revista Cosmopolis, de 1897, Mallarmé indica que a única novidade do poema é relativa ao seu "espaçamento": "le tout sans nouveauté qu'un espacement de la lecture" ("o todo sem novidade a não ser um espaçamento na leitura"). Ele não se considerava em posição de romper definitivamente com a tradição, ou seja, com o verso livre. Excesso de modéstia talvez, ou pura timidez, excesso de precaução também e medo de desagradar seus contemporâneos. $\mathrm{O}$ fato é que o poeta tem consciência 
de participar "com imprevisto, às buscas particulares e caras ao seu tempo, o verso livre e o poema em prosa” (MALLARMÉ, 1998, p. 391).

Mallarmé não foi durante toda a sua carreira um defensor do verso livre. Muito pelo contrário, grande parte da sua obra foi escrita com versos tradicionais. Para entender o que o levou a tal mudança basta olharmos para o cenário poético de França, dos anos 80 do século XIX.

É notável a distância formal que separa Un lance de dados da poesia mallarmeana anterior. Como Murat observa, as únicas "inovações" que Mallarmé realiza desde "L'après-midi d'un faune", de 1866, até "Prose", de 1875, são simplesmente alterações na cesura do alexandrino. O "fauno", por exemplo, é construído com um ritmo irregular, que deixa de lado a regra da cesura no hemistíquio. Esse verso poderia ser definido como "todas as combinações possíveis de doze timbres", que embora não caracterize uma ruptura com a poesia anterior, custou ao poeta uma recusa da segunda edição do Parnasse contemporain. Entre este período e a publicação de Um lance de dados, uma grande transformação deve ter ocorrido para que o verso deixasse de ser uma combinação de doze timbres para se tornar "polimorfo", apenas ritmo e estilo, expressão pessoal e individual do poeta, sinônimo, poderíamos dizer, de poética. Algo deve acontecido para que Mallarmé deixasse de lado seu lado conservador e afirmasse em entrevista a Jules Hurêt, que já era tempo de o alexandrino "descansar". Segundo o autor, devemos supor que neste intervalo, um conjunto de fatores veio modificar a concepção que Mallarmé tinha da literatura e de sua própria obra, historicizando-a sem, no entanto, traí-la.

Os fatores que poderiam ter contribuído para esta tomada de posição no interior do campo literário foram, segundo o autor, a recepção positiva da obra do poeta, sobretudo "Les poètes maudits", de Verlaine e "À rebours", de Huysmans. Textos que permitiram com que o poeta adquirisse uma consciência renovada de sua obra, pois sua poesia estava, a partir deste momento, definitivamente inscrita na história da literatura.

O "lance de dados" se inscreve historicamente, se torna possível, como o próprio poeta aponta, devido a outras "invenções" de seu tempo, como o verso livre e o poema em prosa. Essas novas formas permitiram que o poema eclodisse e dispersasse com ele o verso. No entanto, como pretendemos demonstrar, o poema ultrapassa a forma do verso livre, ele se constitui a partir de outro paradigma. Daí a insistência do poeta no prefácio do poema em se comparar aos seus contemporâneos, guardando ao mesmo tempo certa distância. Na verdade, Mallarmé vai além do verso, além da métrica e define o espaço da página como o responsável pela apresentação da Ideia, de seus gestos.

Como nos mostra Laurent (2002, p. 57), a partir do trabalho crítico de Roubaud, o verso livre não pode se definir sintaticamente como outrora se definia o verso, nem como unidade fonológica, nem mesmo pelo ritmo. O verso livre "só tem existência visual". Mallarmé parece ter, em pouco tempo, compreendido o que estava em jogo no verso livre. Ele foi um dos primeiros entre os que souberam aproveitar o caráter espacial do novo verso e de utilizá-lo para criar novos paradigmas literários. Para Mallarmé, o verso também não é uma unidade sintática ou fonológica, o verso, através da sua espacialização, recebe o nome da operação que realiza uma "subdivisão prismática da ideia" ("subdivisions prismatiques de l'idée").

Citamos mais uma vez o prefácio do poema, no qual o poeta explica como essas subdivisões operam: "O papel intervêm cada vez que uma imagem, ela mesma, cessa ou entra, aceitando a sucessão de outras e, como não se trata, como sempre, de traços sonoros ou regulares do verso - mas antes, de subdivisões prismáticas da Ideia." (MALLARMÉ, 1998, p. 391) 
A forma de uma ideia é determinada pelo espaço que se torna um aliado do poeta, ele contribui para gerar significado tanto quanto as próprias letras, por isso Mallarmé sempre ressalta a importância dos espaços em branco de seus poemas. Se a imagem se torna fragmento da ideia, ela pode ser reforçada pelos caracteres das letras, fazendo com que os "gestos da ideia" tenham sua relevância ressaltada pelo tamanho e pelo negrito ou itálico das letras, como se os diferentes caracteres tipográficos correspondessem aos tons e timbres musicais.

Os diferentes caracteres tipográficos são utilizados para distinguir diversos "motivos" do poema, enquanto os espaços em branco organizam sua disposição em torno do motivo principal, como uma constelação de letras. Os motivos do poema, Mallarmé os distingue em "preponderantes", "secundários" e "adjacentes", além do motivo principal que é a própria frase-título do poema, cada um desses motivos recebe um caracter especial. As "subdivisões prismáticas da ideia" se organizam, através dos caracteres, em diversos motivos, as imagens entram e saem de cena, elas se ligam e se desligam do motivo principal, da frase título girando em torno dela como uma constelação. O motivo preponderante é formado por: UN COUP DE DÉS / JAMAIS / N'ABOLIRA/LE HASARD; o primeiro motivo secundário seria: Si / c'était / le nombre / ce serait — que possue como termos adjacentes: comme si / comme si, e diversas outras ramificações, o motivo secundario: (com muitos adjacentes): quand bien même lance dans des circonstances éternelles / du fond d'un naufrage / soit / le maître / existât-il / commençât-il et cessât-il / se chiffrât-il / illuminât-il / rien / n'aura eu lieu/ que le lieu / excepté/ peut-être / une constellation; outros motivos adjacentes estão representados pelas letras menores.

Cada motivo tem sua importância definida pelo tipo e tamanho do caráter além do espaço que ocupa na página. E, além disso, o espaço funciona para criar um ritmo de leitura, a altura da página em que as palavras aparecem determinaria assim a entonação da leitura. Como indica o poeta: "os caracteres de impressão [...] ditam sua importância na emissão oral e a dimensão, media, alta, em baixo da página, notará que sobe ou desce a entonação." (MALLARMÉ, 1998, p. 391-392)

O tamanho das letras, assim como os caracteres, indica sua importância na constituição do poema, sua entonação, contribuem para definir um ritmo individual, baseado no espaço, no caráter visual do poema. Além disso, o espaço cria um sentido de leitura, os caracteres sempre realizam um movimento de descida na página, como Igitur que desce ao fundo do espírito humano, mas longe de mergulharem num abismo, eles aparecem na página seguinte, mais uma vez nas alturas. Esse sentido é mais que espacial, como o espaço é mais que uma transposição da organização sonora, os timbres e alturas, sonoros ou espaciais, organizam pares de contrários, oposições entre letras maiores ou menores, em negrito ou itálico, no alto ou em baixo da página, entre sons distintos, sonoridades "abertas", "fechadas" etc., como se todo poema se estruturasse a partir de oposições. Seguindo a oposição fundamental das Letras, entre o negro da escrita e o branco da página, presente também nos dados, onde os números são símbolos negros sobre a face branca e que, figura, portanto, a própria oposição entre razão, pensamento e acaso, criação poética e contingência. Em uma nota manuscrita, recentemente publicada, lemos:

Podemos subir com caracteres maiores

Eles servem para isso

- os do texto descem sempre e essa descida da página - este sentido- é conforma a sombra dos caracteres preto sobre branco, que cavam o mistério de cada página se acumulam (e rejeitadas se lidas) para deixar eclodir à altura o texto na página seguinte. (MALLARMÉ, 1998, p. 407) 
O poema é através do espaço um movimento de descida e subida, uma elevação em direção à ideia, um mergulho no espírito humano, uma escavação da linguagem, que procura fazer o céu se refletir no espaço do poema. Os caracteres tipográficos representam o movimento do mar, por onde o mestre navegava com quem ele luta, contra as forças da natureza, contra os limites do homem, contra as próprias palavras, ou deveríamos dizer, contra os números, contra o acaso que faz rolar os dados, contra a numeração do verso, contra a métrica. O poema efetua uma descida que é um mergulho nas profundezas das circunstâncias eternas em que ele ocorre, um naufrágio, momentâneo, pois na página seguinte tudo recomeça, as letras como que espelhadas no céu aparecem nas alturas, concorrendo com as estrelas. Movimento em que o poema se faz se coloca em questão diante dos nossos olhos, ele se procura, entre os números e as letras, se elabora, se dissolve, é, desaparece e reaparece.

Mas a definição do espaço como operador "das divisões prismáticas da ideia" não resolve a questão do verso livre e muito mesmo explica a relação de Mallarmé com a tradição poética, com a qual o poeta jamais rompeu definitivamente.

Se Mallarmé é tão contraditório nas afirmações que concernem o verso livre e o verso tradicional é porque a questão do espaçamento do poema, como vimos anteriormente é a questão mesma do verso livre. Neste momento, nos primeiros anos de seu aparecimento, o verso livre já era compreendido como definido pelo espaço. Sendo assim, a questão da métrica é sempre ambígua, pois podemos entender que o poema é composto de diversos metros, dispostos ao longo da página, de tal modo que se as palavras forem reagrupadas e os espaços encurtados, então se obtêm a métrica "real" do verso, que pode aparecer como um octossílabo, um dodecassílabo, etc. Isso quer dizer, na prática, que o verso metrificado continua presente no verso livre, ele é sua referência, mesmo que implícita, e é só em relação a ele que o verso não metrificado pode ser dito livre. Esta leitura se baseia nas declarações do poeta, que afirma jamais ter rompido inteiramente com a tradição, conforme consta do prefácio do poema: "Os "brancos", com efeito, assumem importância, surpreendem primeiramente; a versificação exige, como silêncio em torno, ordinariamente, ao ponto que um trecho, lírico ou de poucos pés, ocupa, no meio, um terço da folha: eu não transgrido esta medida, somente a disperso." (MALLARMÉ, 1998, p. 391)

Nesta afirmação encontramos a confirmação de que os espaços em branco contribuem para compor o verso, que aparece simplesmente "disperso" na página. Assim, Mallarmé não cede inteiramente à novidade, mas expõe o que o verso livre é de fato, um verso que só pode ser dito livre em relação ao verso metrificado, portanto, que precisa da métrica para se definir. Mallarmé declarou também na mesma entrevista a Jules Huret, que o alexandrino deveria ser guardado, reservado para ocasiões solenes. Ora, a frase título do poema parece ser uma ocasião deste gênero, pois se trata de afirmar a irredutibilidade do acaso. Por isso o poeta utiliza um metro, que não é o alexandrino, mas que faz referência a ele, o verso de treze sílabas, quase um verso falso "Un coup de dés jamais n'abolira le hasard". Desta maneira, o poeta joga com o acaso e com a tradição, procura ironizar o metro tradicional e ao mesmo tempo utilizá-lo para conferir um caráter "solene" à sua afirmação.

\section{A oralidade em Um lance de dados}

Tratamos anteriormente do caráter visual, espacial do poema que compõe um dos elementos da linguagem, a escrita, ou as Letras. Examinamos a questão dos caracteres tipográficos na construção do sentido e da configuração espacial do poema, assim como na 
configuração do próprio verso. Vamos agora examinar de que maneira o poema se constitui enquanto "fala", sonoramente, ou como a Música determina a configuração do poema, contribui na constituição de uma linguagem menos representativa e mais abstrata, mais próxima das Ideias.

Nos manuscritos das Notas sobre a linguagem, o caráter oral desta aparece não somente teorizado através do conceito de "fala" (parole), mas também através da ideia de conversação.

\begin{abstract}
a Conversação; não em uma conversa, o que ela é no momento( acabou) nem na parte de sua abstração que nos queremos conhecer, mas na sua Ficção, aqui assim como ela é expressa com relação à essas duas fases que ela reflete. Chegar da frase à letra, pela palavra; servindo-nos do signo ou da escritura, que liga a palavra ao seu Sentido. (MALLARMÉ, 1998, p. 508)
\end{abstract}

O poeta busca definir não o caráter momentâneo de uma conversa, nem seu caráter abstrato, mas o caráter ficcional da conversação, que se constitui a partir das duas fases que ela reflete. A conversação poderia ser chamada também de conversão, pois examina o processo de escrita e de leitura que incessantemente transforma a escrita em fala e o som em escrita. Assim, temos que a conversação é composta por um primeiro movimento que vai da frase à letra; que ainda não sentido. O segundo movimento deve se servir do signo, da escrita ou das letras para ligar a palavra ao seu sentido. Assim, a letra é antes de mais nada signo, quase um objeto, não ainda um símbolo, mas apenas índice, ela indica algo além de si mesma, o sentido que virá depois.

Mas a conversação não é somente escritura, transformação da palavra em signo, do signo em sentido. Ela é também, tal como a leitura, fala, som. A frase passa à letra, se torna signo, palavra escrita, e enfim, num segundo momento, o momento da leitura, que realiza o sentido inverso da escrita, que contribui igualmente para o sentido, passando do signo escrito à fala, ao som. Essas duas fases da "conversação" representam os dois momentos da linguagem, além disso, ela vai além da "fala", do som, ela implica troca. Esta troca se realiza no interior da própria linguagem, justamente porque a "conversação" não é apenas signo ou som, ela é a união destas duas fases da linguagem.

A "conversação" é a dissolução da escrita através do seu tornar-se outro, seu tornarse fala. Enquanto "procedimento essencial da linguagem", ela possui um caráter duplo. De um lado, ela constitui uma abstração; de outro, o poeta afirma a importância de compreendermos a "conversação", "tal qual ela aparece em sua manifestação habitual e tal qual a possuímos no caso presente." (MALLARMÉ, 1998, p. 508). A “Conversation” se define como uma abstração, pois ela "permite uma abstração de nosso objeto, a Linguagem, ao mesmo tempo em que espaço da Linguagem, ela permite oferecer seu momento à Ciência" (MALLARMÉ, 1998, p. 508). Homem, Espírito, Linguagem se definem, no seu momento presente, como Mallarmé diz, ou a partir de suas manifestações, onde a presentificação é a apresentação conceitual. Mas, o momento presente, é negativo, é um devir, ao mesmo tempo um momento de irrupção, onde a fala se escreve, e de dissolução, onde ela se torna som mais uma vez.

Nos rascunhos que Mallarmé deixou do poema, ele define seu caráter oral, a partir do caráter efêmero e abstrato da "fala": "a fala se profere como sons à inteligência, no ar e por assim dizer musicalmente”. (MALLARMÉ, 1998, p. 403).

Retornemos ao prefácio: 
Sua reunião se realiza sob a influência, eu sei, estrangeira, a da Música escutada no concerto; reencontramos diversos meios que me parecem pertencer às Letras, eu os retomo. O gênero, que se torne um como a sinfonia, pouco a pouco, ao lado do canto pessoal, deixa intacto o verso, ao qual guardo um culto e atribuo o império da paixão e dos sonhos. (MALLARMÉ, 1998, p. 392)

Para escapar da noção representativa da linguagem, o poeta constrói outra via, outro modo de trabalhar a linguagem, a Música. Ela deixa intacto o verso e seu império sobre as Letras, dissolve os objetos através do recurso a uma sintaxe particular que permite que muitas relações se estabeleçam entre as palavras. A indeterminação sintática aproxima as palavras umas das outras, permitindo que além da sintaxe, as relações se dêem através dos sons. O espaço é então utilizado para criar um ritmo, ditar entonações, enquanto os espaços em branco consomem o negro das letras e dissolvem toda fala, para transformá-la em ideia.

Poderíamos citar como exemplo do funcionamento "musical" do poema, a frase título: "Un coup" (um lance), sonoridade obscura, fechada, no entanto, o ato de lançar os dados parece ligeiro, leve. Lançar os dados é abrir um horizonte de possibilidades infinitas, a significação da palavra parece estar na contramão do som que ela possui, mas essa contradição é atenuada pelo vocábulo "de dês" (de dados), som aberto, luminoso, a repetição da letra "d" garante ainda mais suavidade a esses termos. Em seguida, temos "Jamais" (jamais), sonoridade clara e aberta para uma palavra que indica, na verdade, uma negação, uma impossibilidade, uma restrição. "Jamais" poderia também indicar uma possibilidade, se o termo viesse precedido de um "si", mas não é o caso no poema. Aqui ele indica a total impossibilidade de abolição do acaso. Em seguida temos, "n'abolira" (abolirá), que contém uma negação, "n"”, que reforça ainda mais a negação que "jamais" porta; outra palavra com sentido negação, "abolição", mas que possui, no entanto, um som neutro, digamos entre "coup" e "dés", nem muito fechada, nem muito aberta. Uma neutralidade que contrasta com a forma da palavra, que definitivamente encerra as possibilidades que o lance de dados inaugura. Não consideramos aqui o lugar que os vocábulos ocupam nas páginas do poema, mas o leitor pode observar que, frequientemente, o espaço visa neutralizar o som e o sentido, contrabalanceando-os, como se o espaço fosse mais um elemento na constituição do sentido. ${ }^{2}$

Mas, como mencionamos, a oralidade do poema se configura não apenas através dos sons das palavras, mas como ideia mesma de poesia. Mallarmé ressaltou muitas vezes que o verso livre permitia um tipo de articulação "individual”, ele tornava possível que um poeta desenvolvesse um estilo próprio, pessoal, único. Meschonnic (1985, p. 41) desenvolve uma teoria da voz poética a partir desta hipótese de leitura do poema. No prefácio de Ecrits sur le Livre, de Mallarmé, Meschonic (1985) constata que a impessoalidade não caracteriza em nada um não sujeito, mas sim o trabalho do poeta que cede a iniciativa às palavras. $\mathrm{O}$ sujeito, segundo o autor, é a passagem da subjetividade na e para a linguagem. Essa subjetividade se constitui na prosódia que acompanha a escrita do poema, "ato de individuação" que o autor nomeia "fala", "parole", união entre a oralidade, enquanto primado do ritmo / e a voz, ato de individuação, ou o próprio verso. Ou seja, a fala seria uma aliança entre o ritmo e o sujeito. Para Mesconnic (1985), ligar o individual e o oral deixa transparecer que a subjetividade e a historicidade são solidárias e presentes na voz. Desta forma, a poesia é recolocada na oralidade, portanto, no sujeito, com sua historicidade.

A ideia de Meschonnic pode ser válida se admitirmos uma leitura oral do poema, no entanto, essa questão não está clara e já gerou diversas polêmicas. Laurent (comenta

\footnotetext{
${ }^{2}$ Ver: Cohn, Robert Greer. L'oeuvre de Mallarmé. Un coup de dés. Trad.: René Arnaud. Paris: Les Lettres, 1951.
} 
essa questão em La fin de l'intériorité, ele se opõe à leitura de Meschonnic e utiliza como justificativa a descrição que Valéry faz da leitura que o próprio Mallarmé teria feito do poema, em sua presença, o que testemunha seu caráter eminentemente "mental". Mas o que definitivamente impede uma leitura "oral" do poema é, para Laurent, sua configuração espacial, que nenhuma performance oral é capaz de "representar" (como configuração espacial entende-se a posição de cada palavra na página, a dupla página ou a "dobra", o tamanho de cada vocábulo, os caracteres tipográficos, seu regime de constituição e as relações que cada um desses elementos estabelecem visualmente e que contribui para gerar significados.)

Como o autor afirma, o poema se configura no espaço da página que representa o espaço mesmo do pensamento, tal como em Igitur, a inteligência do leitor deve colocar as palavras no seu devido lugar. No poema, o pensamento toma forma, se exterioriza, mas essa exteriorização não se dá somente devido à solidez dos caracteres na página, ao contrário, a forma da exteriorização do pensamento, a forma do poema se constitui a partir da contradição entre a fala e a escrita. Como o próprio poeta ressalta, o poema, na sua própria constituição espacial resulta, para quem pretende lê-lo em voz alta, numa partitura: "Acrescentamos que este emprego à nu do pensamento com retrações, prolongamentos e fugas, ou seu próprio desenho, resulta, para quem quer ler em voz alta, numa partitura". (MALLARME, 1998, p. 391) Uma partitura que cabe ao leitor interpretar e executar.

Considerar o poema apenas em seu aspecto visual, sem levar em consideração seu aspecto oral, transforma o poema num "gênero" semelhante à sinfonia, como o próprio poeta enfatiza. Isso equivale a afirmar, com Blanchot (1959, p. 318), que no poema Um lance de dados: "O acaso é senão vencido, ao menos atirado no rigor da fala e elevado à sólida figura de uma forma onde ele se encerra." Ora, a fala e igualmente o aspecto visual do poema colaboram para criar a impressão e a aparência de que o poema é puramente casual, não a realização racional, fruto do cálculo, mas a própria forma do acaso, sua realização máxima. É na fala e no espaço que o poema, ao invés de se fechar sobre si mesmo, abre um infinito de possibilidades, inclusive de possibilidades de leitura e interpretações, uma vez que cada palavra vista ou pronunciada se dissolve e recomeça, incessantemente, sem encontrar um ponto último que o sacralize, no limite onde "toda a realidade se dissolve". Assim, ele esta sempre aquém ou além do acaso e não pode se restringir à sua forma que seria, na verdade, a ausência total de forma.

Por isso é preciso manter o equilíbrio entre os dois aspectos do poema: o oral e o visual, uma vez que um constitui e contradiz o outro, sem que se anulem. Pelo contrário, criam novas possibilidades de sentido, configuram o próprio sentido, no seu movimento. A coreografia do poema se realiza na interface visual e oral, no espelhamento destes dois aspectos de onde emergem significações múltiplas, indefinidamente. Esta sim seria a verdadeira forma do acaso, uma forma que nunca se encerra, que não se deixa restringir, onde o acaso não é mimetizado ou controlado, mas onde ele aparece como elemento constituinte da própria forma, capaz de transformá-la do seu interior e impedir que ela se fixe completamente. Só assim o acaso pode aparecer como algo além de uma presença fulgurante e instantânea, como um verdadeiro processo, como devir.

Trata-se, portanto, de encontrar um equilíbrio entre o acaso e o pensamento, entre a forma e a não-forma, entre o passado, o presente e o futuro, trata-se de deixar que o movimento evanescente da fala se inscreva no poema, deixe traços de sentido no papel. $\mathrm{O}$ que está em questão nesta relação entre letras e música, entre tempo e espaço é expor o que se constrói no movimento fugaz de passagem do tempo, expor o espaço onde o tempo se desenvolve. O que está em jogo neste lance de dados é a constituição de uma forma, de um modo de presença capaz de ser ao mesmo tempo passado, presente e futuro, presença 
fulgurante, no entanto, permanente. Trata-se de fixar esta luz, este lampejo que eclode no choque entre as palavras, na sua reflexão mútua. Este jogo de espelhos é possível através de outro recurso formal inovador, a página dupla.

\section{A página dupla: a dobra}

Mallarmé via na dobra da página do jornal, que é também a dobra das páginas do Livro, um índice "quase religioso", um elemento constitutivo do ato de leitura, da própria criação poética. Uma página que se dobra, se volta sobre si mesma e se encerra, como num túmulo. Assim, uma página virada é uma página morta, deixada para trás, um segredo guardado. Além disso, a dobra da página representa um movimento, caro ao poeta, que é o da reflexão, este voltar-se sobre si mesmo. No texto "Le livre, instrument spirituel" (O livro, instrumento espiritual), de Divagações, o poeta define o papel da dobra da página na configuração do Livro, ou de sua ideia de Literatura. "A dobra é, em face da folha impressa grande, um índice, quase religioso; que não impressiona tanto quanto seu empilhamento, em espessura, oferecendo o minúsculo túmulo, certamente, da alma." (MALLARMÉ, 2010, p. 181)

Esta dobra indica que um Livro é, a princípio, fechado sobre si mesmo e por ser composto de uma sucessão de dobras, se produz este "empilhamento". Desta maneira um Livro não passa de uma pilha de papel que se articula somente através desta dobra que liga uma página a outra, que as faz dobrar-se umas sobre as outras, para melhor esconder o segredo que guardam. Essas páginas fechadas umas sobre as outras, como num minúsculo túmulo, não podem guardar outro segredo a não ser o da nossa própria alma, um livro como um túmulo encerra definitivamente toda a verdade sobre nós mesmos.

\footnotetext{
Até o formato, ocioso: e, em vão, concorre esta extraordinária, como um vôo recolhido, mas prestes a se alargar, intervenção da dobradura ou o ritmo, inicial causa que uma folha fechada, contenha um segredo, o silêncio aí permanece, precioso e signos evocatórios sucedem, para o espírito, a tudo literalmente abolido. (MALLARMÉ, 2010, p. 181)
}

A página dupla evoca uma metáfora muito presente na obra mallarmeana, trata-se do "hymne", ou "hymen", termo que o poeta utiliza para designar a união de dois termos opostos. "As dobras perpetuarão uma marca, intacta, convidando a abrir, fechar a folha, segundo o mestre. Tão cego e pouco um procedimento, o atentado que se consuma, na destruição de uma frágil inviolabilidade.” (MALLARMÉ, 2010, p. 183)

A dobra, ou este hímen, funciona como véu, pois cada página virada rompe com a inviolabilidade do texto, com a virgindade do escrito, que se revela ao leitor. Assim, cada página virada é uma aparição, um desvelamento, uma revelação. A "dobra" se assemelha assim à ideia de reflexão, termo que também implica um duplo, termo que gera um duplo, uma imagem, a página dividida em duas não reflete seu outro lado, apenas se fecha sobre si mesma. Ou seja, apenas a página dupla, que ignora a dobra das páginas, permite que um lado da página se espelhe no outro, dialogue com o outro e nele se reflita. A página dupla permite um movimento de ir e vir, que é a verdadeira reflexão, um ir além dos limites do Livro, que a dobra na página impede, encerrando, como mencionamos, ao virar a página, um segredo.

Retomando as "subdivisões prismáticas da ideia", termo que Mallarmé (1998) utiliza para caracterizar sua utilização do verso livre neste poema, elas são possíveis porque a página dupla permite o espelhamento das palavras, elas se refletem umas nas outras, tornando o movimento da leitura similar ao de um barco que navega por um oceano 
tumultuado. O espaço reflete o som, a imagem mimetiza o próprio movimento do sentido, ondulante, um ir e vir repetitivo que não faz outra coisa a não ser girar em torno de si mesmo, como numa constelação. Se as estrelas fornecem aos navegantes um caminho, uma direção, o verso livre, multiplica as direções, e com uma visão dupla da página, as direções do sentido se multiplicam igualmente. Como o poeta indica, no prefácio do poema: "a vantagem, se tenho direito a dizê-lo, literária, desta distância copiada que mentalmente separa os grupos de palavras e as palavras entre si, parece acelerar ora e retardar o movimento, escandindo-o, intimando mesmo de acordo com uma visão simultânea da página." (MALLARMÉ, 1998, p. 391)

Esta nova configuração da página favorece a configuração do ritmo do poema, que passa a ser estabelecido visualmente. Além disso, o espaço separa e aproxima palavras e grupos de palavras "mentalmente", o que quer dizer que ele funciona "sintaticamente" e, sobretudo semanticamente, diríamos, criando significações, determinando verdadeiros sentidos de leitura.

De acordo com Laurent (2002, p. 65), a inovação de Mallarmé quanto ao verso simbolista, está no que ele chama de "absolutização subjetiva", que consiste em reconhecer a natureza espacial do verso livre e de buscar transpor no espaço a estrutura métrica, por essa razão a estrutura fundamental do poema é a página dupla. Além disso, Mallarmé deixa de lado o conceito de expressão da interioridade em nome da ideia de "representação" do pensamento, e faz do espaço um aliado da música na construção desta representação, como indica Laurent neste trecho: "A novidade, com relação ao simbolismo, é que por um lado o "pensamento" não é mais entendido como "expressão" da interioridade, mas como "representação", por outro lado, o espaço sucede a música como instrumento desta representação." (LAURENT, 2002, p. 65).

Mas, Mallarmé (1998) não apenas deixa de lado a ideia de expressão da interioridade como renova o conceito de "expressão" (a mera exclusão da noção de "expressão" da poesia mallarmeana nos impediria de indicar o caminho que a poesia lírica parece seguir deste Baudelaire, um caminho trilhado a partir da crítica da noção de expressão e de interioridade). A ideia de representação também não parece satisfatória para indicar a natureza da ideia de forma que Mallarmé (2003) parece construir, bem como sua dimensão na história da estética, uma vez que, para o poeta, o pensamento realiza seu próprio movimento no espaço do poema. A noção de apresentação indica um conceito de presença renovado. A forma realiza seu próprio conceito, como se entre o dito e o que se diz não houvesse mais distância, distância que constitui no caso a ideia de representação.

E é justamente a dupla página que permite este abandono do conceito de representação. A página dupla, onde a dobra não é mais dobra, porque ela se desdobra, e se expande, simboliza este movimento reflexivo do poema. Ela permite que o poema se espelhe, se reflita, seja reflexão sobre sua criação, sobre suas condições de existência, sobre suas possibilidades formais. A página dupla é um espaço de reflexão por excelência, onde poema e pensamento são um só.

Para Laurent (2002), o poema tipográfico se torna figura do pensamento, não mais como tradução da interioridade, mas como exterioridade inteligível. Mallarmé (1998) diria que as palavras, as frases, os movimentos que elas apresentam são os próprios gestos da ideia. Não podemos mais falar em interioridade, certamente, pois o poeta exclui a figura do autor, no entanto, o poema ainda conta com seu alter-ego, digamos, o mestre, ou o próprio metro. Para explicar melhor essa ideia vamos reconstituir o que parece ser a "ação" central do poema.

"O MESTRE" "surge" para lançar os dados, no entanto ele "hesita", "ancestralmente a abrir as mãos" buscando o único número que não pode ser outro. Mas, 
um "demônio imemorial" induz diante de oposições nulas, o velho em direção a uma conjunção suprema com a probabilidade. Este demônio imemorial, nascido de um embate, o mar pelos ancestrais e os ancestrais contra o mar, teria uma chance ociosa, luta por um "noivado", por uma união desejada entre o pensamento e o acaso, que poderia abolir o acaso. Mas, o velho sabe que isso é uma loucura. Uma loucura que só pode ser pensada como hipótese, possibilidade, sob o modo do "comme si", como se uma insinuação simples girasse em torno do abismo, como se uma pluma solitária pudesse imobilizar a brancura rígida e derrisória que se opõe ao céu, como se uma sereia aparecesse numa rocha para impor limites ao infinito. Pois se houvesse um número, "ele existiria, começaria e terminaria, se enumeraria e iluminaria", seria o próprio acaso. Por consequiência, "nada" foi desta memorável crise, apenas "um acontecimento realizado em vista de todo resultado nulo", "nada teria acontecido", "nada teria tido lugar" a não ser o lugar, o acontecimento nulo, humano. Como se Mallarmé se perguntasse: "Alguma coisa como as letras existe de fato?" Não se trata apenas de números no universo, não é assim no céu, não é assim na economia? Este acontecimento humano, a literatura, é por isso, nulo, ele nada realiza, tratase apenas de ficção (pouco menos do que uma probabilidade, uma simples possibilidade), apenas poesia, pois nada aconteceu a não ser o próprio poema, que "pela sua mentira teria fundado a perdição", "onde toda realidade se dissolve". Assim, a poesia é uma exceção, um espaço onde nada acontece, a não ser a própria poesia, um espaço em fusão "com o além", uma constelação que enumera o "choque sucessivo" de "um cálculo total em formação", antes de encontrar um ponto último que o sacralize.

O pensamento poético é um cálculo como num lance de dados. Ele "escolhe", "determina" os números, ele enumera o mundo, o nada, o infinito. O cálculo poético é capaz de fazer com que todas as estrelas caibam numa folha de papel. Fazer poesia nada mais é do que encontrar o bom número, o número certo, que não poderia ser outro. Deveríamos pensar que a poesia deve na verdade escolher palavras, mas, para Mallarmé (1998), o calculo é feito em torno dos números, a poesia enumera as palavras. Calcular é pensar, mas não é preciso ser um grande gênio matemático para saber que as probabilidades pouco têm a dizer sobre poemas ou lances de dados. Não há cálculo de probabilidade capaz de vencer o acaso, o acaso que faz com que os dados caiam numa posição e não em outra. $\mathrm{O}$ cálculo vale para o momento anterior ao ato e, para cada novo lance, a cada vez que os dados são lançados ou a cada resultado do lance, o cálculo não pode dizer mais nada e o acaso é (re) instaurado. No entanto, uma vez que as palavras são fixadas pelas letras no papel, o acaso é abolido, elas ocupam o seu devido lugar, são absolutamente necessárias e irrevogáveis.

Pensemos na frase título do poema: "Un coup de dés jamais n'abolira le hasard" ("Um lance de dados jamais abolira o acaso"), que possui treze sílabas com ritmo bem irregular (4-2-4-3), um verso falso, ou simples acaso? De uma maneira ou de outra ele é uma recusa ao alexandrino que não deixa de ser uma referência ao verso oficial. $O$ jogo, com o acaso, aparece formalmente figurado na relação entre o verso tradicional e o verso livre. $\mathrm{O}$ "mestre" não é, portanto, apenas um personagem que confere um tom épico à narrativa, ele figura a própria luta do poeta contra o acaso, pois ele é uma figuração do próprio poeta e ao mesmo tempo do próprio verso "metro". O mestre hesita em lançar os dados, hesita em empregar um "metro", pois sabe que o acaso não pode ser abolido, que é sempre o acaso que realiza sua própria ideia. Mallarmé não escolheu os dados por acaso, seu número máximo é justamente 12 , o número de sílabas de um alexandrino, bem como a hora fatídica entre a noite e o dia.

O "mestre", ou o "metro", é o acaso desnudado, sua própria forma, a impossibilidade de vencê-lo, que faz com que o poeta se retire de cena e conceda à 
iniciativa as palavras. Visualmente o poema parece ser a obra em que o poeta desaparece de fato. Isso porque ele não se enuncia, não há "eu" por trás dos verbos, ou por trás do lance de dados. A situação hipotética parece acontecer num espaço inalcançável, no fundo de um naufrágio, seu lugar no tempo é eterno, nada parece de fato acontecer, como se as palavras tivessem de fato assumido o controle e, sem ordem nenhuma, se dispersassem pela página. Porém, é justamente atrás desta desordem que o poeta se esconde. A forma do acaso é por ele construída, num frágil equilíbrio entre controle total e ausência de controle, entre a presença e a ausência do poeta.

Em "Le livre, instrument spirituel" ("O livro, instrumento espiritual"), no qual Mallarmé (2003, p. 226) define o papel da dobra da página do Livro, deixada de lado pela invenção da página dupla, ele discorre sobre o papel do autor na "organização do volume", no ordenamento do Livro.

No que me diz respeito, conheço mal o volume e uma maravilha que intima sua estrutura, se não posso, cientemente, imaginar tal motivo em vista de um lugar especial, página e a altura, à orientação de luz a sua ou quanto à obra. Mais o vai e vem sucessivo incessante do olhar, uma linha terminada, à seguinte, para recomeçar: semelhante prática não representa a delícia, tendo imortalmente, rompido, uma hora, com tudo, de traduzir sua quimera.

A fabricação do Livro, segundo Mallarmé (2003), não tem nada de industrial, ela começa desde sua primeira frase, pois um poeta sempre sabe qual o lugar que seu verso deve ocupar, seja num soneto, seja num Livro, seja num "espaço puro". Para Mallarmé (2003), um autor se deixa ler em seu Livro, na medida em que é ele que organiza o volume, o que quer dizer que ele aparece como forma. A forma é, sobretudo, para o poeta, organização e disposição espacial. Organização que obedece a forma mesma da letra. "O livro, expansão total da letra, deve dela tirar, diretamente, uma mobilidade e espaçoso, por correspondências, instituir um jogo, não se sabe, que confirma a ficção." (MALLARMÉ, 2003, p. 226). Assim, entre as palavras se estabelece um jogo, no espaço através dos diversos movimentos que as letras, as palavras, os sons provocam, este movimento se torna possível entre outras coisas pela página dupla, que na sua própria forma evidencia o caráter reflexivo do poema.

\section{Conclusão}

Assim, na ficção e só na ficção o acaso pode ser abolido, palavra por palavra, para ceder lugar à necessidade que emerge do próprio acaso e que se impõe a partir do choque entre as palavras e dos sentidos que daí emergem. Cada palavra aparece como o signo da mais absoluta necessidade, cada palavra se impõe como única, como àquela que jamais poderia ser outra; elas se justificam e se explicam a partir da sua simples existência singular. Uma vez que o poema se encontra feito, realizado, completo, ele justifica a sua existência, pois é visível e palpável, a maneira das coisas, a maneira dos simples objetos, dos quais nossos olhos não ousam duvidar.

Mas o acaso não desaparece totalmente de cena. Uma vez que as letras ocupam seu devido lugar no espaço em branco e o Livro existe, a cada palavra, a cada espaço em branco, o acaso reaparece, pois ele determina a emergência do significado, ele se renova e reaparece a cada palavra, a cada linha, no vai e vem da leitura. Por isso a existência do poema ultrapassa a materialidade e objetividade das coisas, uma vez que não se deixa fixar e restringir. $\mathrm{O}$ acaso está presente porque a cada nova palavra que aparece no horizonte de 
leitura um sentido que sempre se renova e outras significações surgem. E mesmo quando o poema termina, descobrimos que, na verdade, ele apenas recomeça. Ao fim da viagem percebemos que, neste lance de dados, é o pensamento que está em questão: "toute pensée émet um coup de dés". E somos assim (re) enviados ao começo do poema e convidados, pelo poeta, a mais uma vez, lançar os dados.

\section{REFERÊNCIAS}

BLANCHOT, M. Le livre à venir. Paris: Gallimard, 1959.

KRISTEVA, Julia. La révolution du langage poétique. Paris: Édition du Seuil, 1974.

LAURENT, J. La fin de l'intériorité. Paris: PUF, 2002.

MALLARMÉ, S. Euvres complètes I. Paris: Gallimard, 1998.

MALLARMÉ, S. CEuvres complètes II. Paris: Gallimard, 2003.

MALLARMÉ, S. Divagações. Trad. Fernando Scheibe, Florianópolis : Editora da UFSC, 2010.

MESCHONNIC, H. Mallarmé, au delà du silence. In: MALLARMÉ, S. Écrits sur le livre. Paris: Editions de l'éclat, 1985.

Recebido em: 02 de dezembro de 2011.

Aprovado em: 19 de agosto de 2012. 